\title{
Dormancy-Breaking Requirements and Germination for Seeds of Ostrya carpinifolia Scop.
}

\author{
Elias PIPINIS ${ }^{1 *}$, Elias MILIOS², Olga MAVROKORDOPOULOU ${ }^{1}$, \\ Panagiotis LOZOS ${ }^{1}$, Pavlos SMIRIS ${ }^{1}$
}

\begin{abstract}
${ }^{1}$ Aristotle University of Thessaloniki, Department of Forestry and Natural Environment, Laboratory of Silviculture, 54124 Thessaloniki, Greece; epipinis@for.auth.gr (*corresponding author),olgamavr@for.auth.gr,lozos88@gmail.com,psmiris@for.auth.gr

${ }^{2}$ Democritus University of Thrace, Department of Forestry and Management of the Environment and Natural Resources, Pandazidou 193, 68200 Orestiada, Greece; emilios@fmenr.duth.gr
\end{abstract}

\begin{abstract}
The present research aims at investigating the combined effects of warm stratification (WS)+cold stratification (CS), and gibberellic acid $\left(\mathrm{GA}_{3}\right)+$ cold stratification $(\mathrm{CS})$ on breaking dormancy and germination in seeds of Ostrya carpinifolia. The seeds were subjected to WS $\left(20-25^{\circ} \mathrm{C}\right)$ for 0,1 and 2 months and were subsequently cold stratified at $3-5^{\circ} \mathrm{C}$ for $0,1,2,3$ and 4 months (1st experiment). A further amount of seeds was treated with 500, 1000 or 2000 ppm $\mathrm{GA}_{3}$ for 30 hours and then cold stratified at 3$5{ }^{\circ} \mathrm{C}$ for $0,1,2,3$ and 4 months (2nd experiment). No germination was observed in the seeds subjected to only WS (1 and 2 months) or CS for 1 month indicating that the seeds of $O$. carpinifolia are dormant. A 4-month stratification (1 month WS +3 month CS or 4 month CS) fully released dormancy and led to a high germination percentage ( 94.17 and $98.34 \%$ respectively) in a short time (7.12 and 7.00 days respectively). Warm stratification treatment prior to CS, was not required in order to break the seed dormancy of $O$. carpinifolia and also did not reduce the length of the (total) stratification period required for breaking seed dormancy. Gibberellic acid $\left(\mathrm{GA}_{3}\right)$ application entirely replaced the $\mathrm{CS}$ period required for breaking seed dormancy. The germination of the seeds treated only with 2000 ppm GA 3 (0 months of CS) was (94.17\%) as high as the germination of the seeds subjected to 4 months of CS (98.34\%). It is obvious that the seedcoat of $O$. carpinifolia seeds was permeable to GA $\mathrm{G}_{3}$ and did not mechanically restrict embryo growth, thus, the seeds did not exhibit physical dormancy. Based on dormancy breaking requirements, the $O$. carpinifolia seeds displayed intermediate physiological dormancy.
\end{abstract}

Keywords: cold stratification, gibberellic acid, warm stratification

\section{Introduction}

Plant propagation by seed is the most common method in nurseries. Although the specific method is the cheapest for growing large numbers of plants in the nursery industry, a number of difficulties have been frequently observed in germination due to seed dormancy (Macdonald, 2006). Seed dormancy is a physiological state, in which a viable seed fails to germinate even when placed in environmental conditions (water, temperature, and aeration) favourable for germination (Hartmann et al., 1997).

The genus Ostrya includes nine species, which are distributed in the temperate regions of the Northern hemisphere (Govaerts and Frodin, 1998). Ostrya carpinifolia Scop. is native to Europe and south-west Asia (Browicz, 1982). It is a tree species which mainly grows in the mountain and sub-mountain regions of the continental part of Greece (Boratynski et al., 1992). It is usually found in the understory of deciduous or even coniferous forests, but can also be found in open places, usually on limestone rocks (Boratynski et al., 1992). However, according to
Milios (2000), the species forms pure stands and also dominates (with Fraxinus ornus) in the overstory of mixed stands found in the slopes of the western part of the Nestos valley in north-eastern Greece. The ability of $O$. carpinifolia to grow in dry areas and in shallow soil (Browicz, 1982) makes it suitable for degraded site reforestation.

Propagation using seeds of the specific species is difficult due to seed dormancy. Piotto et al. (2003), to overcome seed dormancy of $O$. carpinifolia seeds, recommended warm stratification followed by cold stratification. Similarly, as far as $O$. virginiana seeds are concerned, to break dormancy, Dirr and Heuser (1987) suggested a combination of warm and cold stratification treatments. Schopmeyer and Leak (1974) (cited in Baskin and Baskin, 1998) maintained that seeds of $O$. virginiana display physiological dormancy. In addition, Leak and Bonner (2008) attributed the failure of $O$. virginiana seed germination to hard seed coat and to internal dormancy. Cold stratification has been widely used as a pre-treatment for breaking dormancy of many northern hemisphere species with physiological dormancy (Baskin and Baskin, 1998). However, in the seeds of some species 
displaying physiological dormancy, cold stratification is not very effective in breaking dormancy unless the seeds first receive a period of warm stratification (Baskin $e$ t al., 1993; Baskin et al., 2002; Pipinis et al., 2012). It is also worth noting that growth regulators, such as gibberellic acid, are used to partially or fully replace the period of cold stratification needed to break physiological dormancy in seeds of many plant species (Baskin and Baskin, 1998).

As there is no literature to document experiments demonstrating the contribution of warm and cold stratification treatments as well as the effect of $\mathrm{GA}_{3}$ on breaking dormancy of $O$. carpinifolia seeds, the objectives of the present study are to i) examine the effectiveness of warm, cold stratification and gibberellic acid $\left(\mathrm{GA}_{3}\right)$ on germination, ii) describe the effects of warm and cold stratification treatment combinations on germination, iii) describe the effects of gibberellic acid and cold stratification treatment combinations on germination, and iv) propose effective treatments to maximize germination percentage of O. carpinifolia seeds.

\section{Materials and methods}

Mature O. carpinifolia fruits were collected in the middle of September 2008 from a number of trees (more than 10) growing in their natural habitat $\left(39^{\circ} 57^{\prime} 49^{\prime \prime} \mathrm{N}\right.$, $21^{\circ} 12^{\prime} 35^{\prime} \mathrm{E}, 800 \mathrm{~m}$ elevation) in northern Greece. After collection, the fruits were spread out in a shaded and well aerated place and then were rubbed by hand in order to separate seed from involucres. Sieving and flotation were used to clean the seeds and to remove non-filled seeds. Then, the clean filled seeds were spread out on filter paper in laboratory conditions and left to dry. After drying, the seeds were stored in a sealed container at $3-5^{\circ} \mathrm{C}$ until the experiments were conducted.

\section{Seed treatment}

The germination experiments started in November 2008 and were conducted in the laboratory of Silviculture, Department of Forestry and Natural Environment, Aristotle University of Thessaloniki. Two experiments were conducted to determine the combined effects of warm stratification (WS)+cold stratification (CS), and gibberellic acid $\left(\mathrm{GA}_{3}\right)+$ cold stratification $(\mathrm{CS})$ on seed germination. In the first experiment, the seeds were mixed with moist sterilized river sand, placed in plastic containers and exposed to WS at $20-25^{\circ} \mathrm{C}$ for 1 and 2 months (there were 2 plastic containers). After each period of WS (1 and 2 months), the plastic container was placed in the refrigerator $\left(3-5^{\circ} \mathrm{C}\right)$ in order for the seeds to be subjected to CS for $0,1,2,3$ or 4 months. In total, 10 treatments (combinations between warm and cold stratification) were applied. A further amount of seeds was treated with $\mathrm{GA}_{3}$ and was subsequently subjected to CS (second experiment). The seeds were soaked in 500, 1000 or 2000 ppm $\mathrm{GA}_{3}$ for 30 hours, and then placed in plastic containers with moist sterilized river sand and exposed to $\mathrm{CS}$ at $3-5^{\circ} \mathrm{C}$ for $0,1,2,3$ or 4 months. There were three plastic containers which corresponded to the three concentrations of $\mathrm{GA}_{3}$. In total, 15 treatments (combinations between $\mathrm{GA}_{3}$ and $\mathrm{CS}$ ) were applied. Moreover, the seeds which were not warm stratified $(0$ month WS) or not treated with $\mathrm{GA}_{3}\left(0 \mathrm{ppm} \mathrm{GA}_{3}\right)$ were subjected to only CS for $0,1,2,3$ or 4 months.

During stratification, sand moisture was periodically checked and water was added, when necessary, to keep it moist.

\section{Germination test}

At the end of each CS period (in both experiments) a random sample of 120 seeds was removed from each plastic container and randomly placed in 4 plastic Petri dishes (30 seeds per Petri dish). For each treatment there were 4 replications of 30 seeds. The seeds were placed on sterilized river sand moistened with distilled water in 9-cm plastic Petri dishes. The seeds were dusted with fungicide, to avoid fungi development prior to their arrangement in Petri dishes which were randomly arranged on the shelves of the growth chamber and were watered - as required - with distilled water.

The temperature in the growth chamber was set at 20 ${ }^{\circ} \mathrm{C}$ for a $16 \mathrm{~h}$ dark period and $25^{\circ} \mathrm{C}$ for an $8 \mathrm{~h}$ light period. The germinated seeds were counted each week for 9 weeks. Notably, a seed was considered germinated when a radicle at least $2 \mathrm{~mm}$ long appeared (I.S.T.A., 1999). Finally, for each treatment, the germination percentage (GP) and the number of days required for seed germination (mean germination time, MGT) were calculated as the average of the 4 replications. For each replication per treatment, MGT was calculated on the basis of the following equation:

\section{$M G T=\Sigma(D \times n) / N$}

where $n$ is the number of seeds which germinate on day $D, D$ is the number of days counted from the beginning of the test and $\mathrm{N}$ is the total number of seeds germinating (Ellis and Roberts, 1981).

\section{Statistical analysis}

In each experiment, a completely randomised experimental design was used. Treatment combinations (WS+CS and $\mathrm{GA}_{3}+\mathrm{CS}$ ), in which none of the seeds germinated or germination percentages were lower than $10 \%$ were not included in the statistical analysis. The GP data were arc-sine square root transformed before analysis (Snedecor and Cochran, 1980). The transformed data were checked for normality and homogeneity of variances and then analysed by one-way ANOVA, and comparisons of the means were made using the Duncan test (Klockars and Sax, 1986). All statistical analysis were carried out using SPSS 20.0 (SPSS, Inc., USA).

\section{Results}

\section{Experiment 1}

There were significant differences in GPs $(\alpha=0.05)$ among the combinations of WS and CS periods $\left(\mathrm{F}_{8,27}=\right.$ $85.41, \mathrm{p}=0.000)$.

None of the $O$. carpinifolia seeds subjected to only WS ( 1 and 2 months) or CS for 1 month germinated (Tab. 1). Seeds subjected to 1 or 2 months of WS followed by a 1month of CS exhibited very low GP. Warm stratification for 1 or 2 months, prior to a 2 or 3 -month CS period significantly improve $(p<0.05)$ seed germination compared to the germination of the seeds only subjected to the same periods of CS ( 2 or 3 months). After 4 months of CS no significant differences $(p>0.05)$ were observed in GPs 
211

among seeds subjected to 0,1 and 2 months of WS. In seeds subjected to 0,1 or 2 months of WS, a significant increase ( $p$ $<0.05)$ in GP was observed when increasing CS duration, except for one case. An increase in the CS period from 3 to 4 months in seeds warm stratified for 1 month did not induce a significant increase in GP $(\mathrm{p}>0.05)$.

The MGT of subjected seeds to WS (for 0,1 and 2 months) and then to CS (from 2 to 4 months) ranged from 7.00 to 9.25 days (Tab. 1 ).

Tab. 1. Germination percentages (GP) and mean germination times (MGT) of O. carpinifolia seeds of all warm stratification (WS) and cold stratification (CS) treatment combinations

\begin{tabular}{cccc}
\hline $\begin{array}{c}\text { WS } \\
\text { (months) }\end{array}$ & $\begin{array}{c}\text { CS } \\
\text { (months })\end{array}$ & GP (\%) \pm S.D. & $\begin{array}{c}\text { MGT (days) } \pm \\
\text { S.D. }\end{array}$ \\
\hline & 0 & 0 & \\
0 & 1 & 0 & \\
& 2 & $11.67 \mathrm{e} \pm 4.30$ & $9.25 \pm 0.92$ \\
& 3 & $75.00 \mathrm{c} \pm 5.77$ & $7.30 \pm 0.24$ \\
& 4 & $98.34 \mathrm{a} \pm 1.92$ & $7.00 \pm 0.00$ \\
& 0 & 0 & $*$ \\
1 & 1 & $2.50 \pm 3.19$ & \\
& 2 & $24.17 \mathrm{~d} \pm 5.00$ & $8.22 \pm 0.40$ \\
& 3 & $94.17 \mathrm{ab} \pm 3.19$ & $7.12 \pm 0.24$ \\
& 4 & $96.67 \mathrm{a} \pm 4.71$ & $7.00 \pm 0.00$ \\
& 0 & 0 & \\
2 & 1 & $3.34 \pm 3.85$ & $*$ \\
& 2 & $33.34 \mathrm{~d} \pm 6.09$ & $7.67 \pm 0.50$ \\
& 3 & $88.33 \mathrm{~b} \pm 4.30$ & $7.07 \pm 0.13$ \\
& 4 & $95.00 \mathrm{a} \pm 4.30$ & $7.00 \pm 0.00$ \\
\hline
\end{tabular}

Means are statistically different at $\mathrm{p}<0.05$, when they share no common letter. The comparisons were made using the Duncan test.

* MGT was not calculated because in one of the four replications, no seed germinated.

\section{Experiment 2}

There were significant differences in GPs $(\alpha=0.05)$ among the combinations of $\mathrm{GA}_{3}$ concentrations and CS periods $\left(\mathrm{F}_{12,39}=31.79, p=0.000\right)$.

The seeds treated only with $\mathrm{GA}_{3}$ (without $\mathrm{CS}$ ) exhibited high GPs (Tab. 2). The seeds subjected only to a 4-month CS period exhibited as high a GP as the seeds treated only with $2000 \mathrm{ppm} \mathrm{GA}_{3}(\mathrm{p}>0.05)$. In the seeds which were not stratified or were cold stratified for 1 month after $\mathrm{GA}_{3}$ application, an influence of $\mathrm{GA}_{3}$ 's concentration on seed germination was observed. In particular, after 0 and 1 month of CS, the seeds treated with $2000 \mathrm{ppm}$ of $\mathrm{GA}_{3}$ exhibited higher GPs than those treated with $500 \mathrm{ppm}$ of $\mathrm{GA}_{3}$ and were subjected in the same period of CS $(\mathrm{p}<0.05)$. After 2 months of CS, no significant differences $(\mathrm{p}>0.05)$ were observed in GPs among the three concentrations of $\mathrm{GA}_{3}$. Significant differences $(\mathrm{p}<0.05)$ in GP among the periods of CS were observed only in the seeds treated with $500 \mathrm{ppm} \mathrm{GA}$. The seeds treated with $500 \mathrm{ppm} \mathrm{GA}$, which were subjected to 3 months of CS, exhibited higher GP than those subjected to 0 or 1 month of CS $(p<0.05)$. A period of CS longer than 3 months, for seeds treated with 500 ppm $\mathrm{GA}_{3}$, was not used, as towards the end of the 3month CS period germinated seeds appeared. Similarly, a period of CS longer than 2 months, for seeds treated with 1000 or 2000 ppm $\mathrm{GA}_{3}$, was not used.

The MGT of treated seeds with $\mathrm{GA}_{3}(500,1000$ and $2000 \mathrm{ppm}$ ) followed by CS (0,1,2 and 3 months) ranged from 7.00 to 12.28 days (Tab. 2).

Tab. 2. Germination percentages (GP) and mean germination times (MGT) of O. carpinifolia seeds of all gibberellic acid $\left(\mathrm{GA}_{3}\right)$ and cold stratification $(\mathrm{CS})$ treatment combinations

\begin{tabular}{cccc}
\hline $\begin{array}{c}\mathrm{GA}_{3} \\
(\mathrm{ppm})\end{array}$ & $\begin{array}{c}\mathrm{CS} \\
(\text { months })\end{array}$ & GP $(\%) \pm$ S.D. & $\begin{array}{c}\text { MGT (days) } \\
\pm \text { S.D. }\end{array}$ \\
\hline & 0 & 0 & \\
0 & 1 & 0 & \\
& 2 & $11.67 \mathrm{f} \pm 4.30$ & $9.25 \pm 0.92$ \\
& 3 & $75.00 \mathrm{e} \pm 5.77$ & $7.30 \pm 0.24$ \\
& 4 & $98.34 \mathrm{a} \pm 1.92$ & $7.00 \pm 0.00$ \\
500 & 0 & $82.50 \mathrm{de} \pm 5.69$ & $12.28 \pm 0.71$ \\
& 1 & $86.67 \mathrm{cde} \pm 4.71$ & $10.94 \pm 0.93$ \\
& 2 & $90.00 \mathrm{bcd} \pm 4.71$ & $7.68 \pm 0.88$ \\
1000 & 3 & $95.83 \mathrm{ab} \pm 5.00$ & $7.00 \pm 0.00$ \\
& 0 & $90.84 \mathrm{bcd} \pm 5.00$ & $10.40 \pm 0.40$ \\
& 1 & $93.34 \mathrm{abc} \pm 3.85$ & $7.75 \pm 0.18$ \\
2000 & 2 & $92.50 \mathrm{abc} \pm 5.69$ & $7.12 \pm 0.14$ \\
& 0 & $94.17 \mathrm{abc} \pm 3.19$ & $9.06 \pm 0.80$ \\
& 1 & $97.50 \mathrm{a} \pm 3.17$ & $7.18 \pm 0.12$ \\
\hline
\end{tabular}

Means sharing the same letters are not statistically different $(p>0.05)$

\section{Discussion}

No seed of $O$. carpinifolia subjected only to WS for 1 and 2 months germinated. In addition, CS up to only 2 months resulted in very low seed germination (11.67\%). The specific results indicate that the seeds of $O$. carpinifolia were dormant. According to Schopmeyer and Leak (1974), (cited in Baskin and Baskin, 1998), the seeds of $O$. virginiana exhibited physiological dormancy. Dirr and Heuser (1987) claim that the seeds of O. virginiana exhibit internal dormancy which is difficult to overcome. In the seeds of $O$. carpinifolia subjected only to CS, an increase in the CS period from 2 to 3 and 4 months significantly increased $(\mathrm{p}<0.05)$ GP. A 4-month CS period led to a high GP (98.34\%) in a short time (7.00 days). According to Baskin and Baskin (1998), in many species of temperate forests, the required CS period to break seed physiological dormancy, depending on the species, is 1 to 4 months.

The seeds subjected to 1 or 2 months of WS, prior to a 2 or 3-month CS period, exhibited higher $(p<0.05)$ GPs than those subjected only to CS for 2 or 3 months. According to Baskin and Baskin (1998), warm followed by cold stratification treatment promotes dormancy break in the seeds of some species with physiological dormancy. The positive effect of WS prior to CS in breaking physiological dormancy was observed in the seeds of Floerkea proserpinacoides (Baskin et al., 1988), Mahonia fremontii (Baskin et al., 1993), Cardamine concatenata (Baskin and Baskin, 1995) and Carpinus betulus (Pipinis et al., 2012). It 
is likely that WS increases the effectiveness of CS in overcoming physiological dormancy. In addition, the seeds subjected to 1 month of WS followed by a 3-month CS period exhibited high GP (94.17\%) similar to the seeds subjected only to CS for 4 months (98.34\%). Thus, a 4-month stratification (1 month WS+3 month CS or 4 month CS) fully releases dormancy of $O$. carpinifolia seeds. Noticeably, WS treatment prior to CS, was not necessary for breaking the seed dormancy of $O$. carpinifolia and, in addition, it did not reduce the length of the (total) stratification period required to break seed dormancy. In contrast, Piotto et al. (2003) recommended 4 to 8 weeks of warm stratification followed by 16 to 23 weeks cold stratification to overcome the seed dormancy of $O$. carpinifolia seeds. Similarly, as far as O. virginiana is concerned, Dirr and Heuser (1987) suggested a combination of warm (3 months) and cold stratification ( 3 to 5 months) treatments to break seed dormancy.

Exogenous $\mathrm{GA}_{3}$ applications have been reported to be effective in breaking dormancy and in substituting for the CS requirement in seeds of many species (Rehman and Park, 2000; Karam and Al-Salem, 2001; Smiris et al., 2006; Deng et al., 2010). The results of the present study demonstrated that the application of $\mathrm{GA}_{3}$ replaced entirely the requirements for $\mathrm{CS}$. The germination of seeds treated only with $2000 \mathrm{ppm} \mathrm{GA}_{3}(0$ months of CS) was (94.17\%) as high as the germination of seeds subjected to 4 months of CS (98.34\%). Pipinis et al. (2012) suggest that $\mathrm{GA}_{3}$ application appeared to replace entirely the requirements for WS, to shorten the required CS period and to promote a satisfactory seed germination of $C$. betulus.

It is also worth pointing out that the results of the present research demonstrate that the seedcoat of $O$. carpinifolia seeds was permeable to $\mathrm{GA}_{3}$ and did not mechanically restrict embryo growth; therefore, the seeds did not exhibit physical dormancy. As far as O. virginiana species is concerned, Leak and Bonner (2008) maintain that the specific seeds, apart from internal dormancy, have also got a hard seedcoat. Thus, based on the dormancy breaking requirements, the $O$. carpinifolia seeds exhibited intermediate physiological dormancy.

\section{Conclusions}

Based on the results of the present research, it can be concluded that the $O$. carpinifolia seeds exhibited intermediate physiological dormancy. A 4-month CS period was required to break seed dormancy. WS prior to $\mathrm{CS}$ was not required for breaking the seed dormancy of $O$. carpinifolia and also did not reduce the length of (total) stratification period required for breaking seed dormancy. However, $\mathrm{GA}_{3}$ application proved to entirely replace the stratification period needed to break dormancy of $O$. carpinifolia seeds.

Thus, for propagation purposes the freshly collected seeds of $O$. carpinifolia should be either cold stratified for 4 months prior to spring sowing or treated with $\mathrm{GA}_{3}(2000$ $\mathrm{ppm}$ ) for 30 hours prior to sowing.

\section{References}

Baskin CC, Baskin JM (1998). Seeds: Ecology, Biogeography, and Evolution of Dormancy and Germination. Academic Press, San Diego, $666 \mathrm{p}$.

Baskin JM, Baskin CC, McCann MT (1988). A contribution to the germination ecology of Floerkea proserpinacoides (Limnanthaceae). Bot Gaz 149:427-431.

Baskin CC, Baskin JM, Meyer SE (1993). Seed dormancy in the Colorado Plateau shrub Mahonia fremontii (Berberidaceae) and its ecological and evolutionary implications. Southwest Nat 38:91-99.

Baskin CC, Baskin JM (1995). Warm plus cold stratification requirement for dormancy break in seeds of the woodland herb Cardamine concatenata (Brassicaceae), and evolutionary implications. Can J Bot 73:608-612.

Baskin CC, Zackrisson O, Baskin JM (2002). Role of warm stratification in promoting germination of seeds of Empetrum hermaphroditum (Empetraceae), a circumboreal species with a stony endocarp. Am J Bot 89:486-493.

Boratynski A, Browicz K, Zielinski J (1992). Chorology of trees and shrubs in Greece. Polish Academy of Sciences. Institute of Dendrology, Kornik, Poland, 286 p.

Browicz K (1982). Chronology of trees and shrubs in south-west Asia and adjacent regions. Vol. 1. Polish Scientific Publishers, Warszawa, Poland, $172 \mathrm{p}$.

Deng ZJ, Cheng HY, Song SQ (2010). Effects of temperature, scarification, dry storage, stratification, phytormone and light on dormancy-breaking and germination of Cotinus coggygria var. cinerea (Anacardiaceae) seeds. Seed Sci Technol 38:572584.

Dirr MA, Heuser CWJ (1987). The reference manual of woody plant propagation: from seed to tissue culture. Varsity Press Inc., Athens, Georgia, 239 p.

Ellis RH, Roberts EH (1981). The quantification of ageing and survival in orthodox seeds. Seed Sci Technol 9:373-409.

Govaerts R, Frodin DG (1998). World checklist and bibliography of Fagales: Betulaceae, Corylaceae, Fagaceae and Ticodendraceae. Royal Botanic Gardens, Kew, 408 p.

Hartmann HT, Kester DE, Davies FT, Geneve RL (1997). Plant propagation: principles and practices. 6th Ed., Prentice-Hall, Inc., Upper Saddle River, New Jersey, USA, 770 p.

International Seed Testing Association (ISTA) (1999). International rules for seed testing. Seed Sci Technol 27, Supplement, $333 \mathrm{p}$.

Karam NS, Al-Salem MM (2001). Breaking dormancy in Arbutus andrachne L. seeds by stratification and gibberellic acid. Seed Sci Technol 29:51-56.

Klockars A, Sax G (1986). Multiple Comparisons. Newbury Park, California: Sage Publications, 87 p. 
213

Leak WB, Bonner FT (2008). Ostrya virginiana (P. Mill.) K. Koch eastern hophornbeam, p. 759-760. In: Bonner FT, Karrfalt RP (Eds). Woody Plant Seed Manual. Agriculture Handbook No. 727, USDA Forest Service, Washington.

Macdonald B (2006). Practical woody plant propagation for nursery growers. Timber Press, Inc., Portland, Oregon, USA, $669 \mathrm{p}$.

Milios E (2000). Structure and development patterns analysis of the Ostrya carpinifolia pure and mixed stands in the western part of Nestos valley. Silva Gandav 65:128-153.

Piotto B, Bartolini G, Bussotti F, Asensio AAC, Garcia C, Chessa I, Ciccarese C, Ciccarese L, Crosti R, Cullum FJ, Noi AD, Garcia-Fayos P, Lambardi M, Lisci M, Lucci S, Melini S, Reinoso JCM, Murranca S, Nieddu G, Pacini E, Pagni G, Patumi M, Garcia FP, Piccini C, Rossetto M, Tranne G, Tylkowski T (2003). Fact Sheets on the Propagation of Mediterranean Trees and Shrubs from Seed, p. 11-51. In: Piotto B, Noi AD (Eds). Seed Propagation of Mediterranean Trees and Shrubs, APAT, Roma.
Pipinis E, Milios E, Kiamos N, Mavrokordopoulou O, Smiris P (2012). Effects of stratification and pretreatment with gibberellic acid on seed germination of two Carpinus species. Seed Sci Technol 40:21-31.

Rehman S, Park IH (2000). Effect of scarification, GA and chilling on the germination of goldenrain-tree (Koelreuteria paniculata Laxm.) seeds. Sci Hortic 85:319-324.

Schopmeyer CS, Leak WB (1974). Ostrya virginiana (Mill.) K. Koch. Eastern hophornbeam, p. 564-565 In: Schopmeyer CS (Tech. Coord.). Seeds of Woody Plants in the United States. USDA Forest Service Agriculture Handbook No. 450.

Smiris P, Pipinis E, Aslanidou M, Mavrokordopoulou O, Milios E, Kouridakis A (2006). Germination study on Arbutus unedo L. (Ericaceae) and Podocytisus caramanicus Boiss. \& Heldr. (Fabaceae). J Biol Res 5:85-91.

Snedecor GW, Cochran WC (1980). Statistical methods. 7th ed. The Iowa State University Press. Ames. Iowa U.S.A, 507 p. 